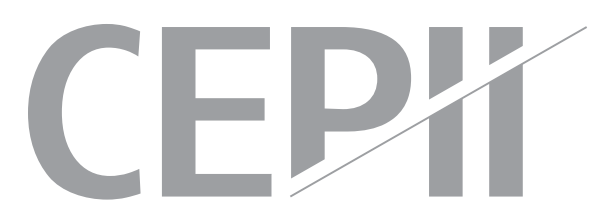

\title{
Tariff Liberalization and Trade Integration of Emerging Countries
}

\author{
Anne-Célia Disdier, Lionel Fontagné \\ \& Mondher Mimouni
}

\section{Highlights}

- We analyze the interactions between tariff cuts and growth in emerging countries' exports over the 19962006 period

- We consider both the extensive and intensive margins of trade

- Our econometric estimations suggest that only the growth in differentiated goods' exports at the intensive margin comes from tariff cuts

- At the extensive margin, export growth is mainly due to a shift in emerging countries' comparative advantage and improvements to their infrastructure. 


\section{Abstract}

This paper investigates how tariff liberalization has affected exporting in emerging countries. We use a highly disaggregated (6 digit level of the harmonized system - HS - classification) bilateral measure of market access to compare tariffs applied in 1996 and 2006, which includes the timing of the Uruguay Round and episodes of bilateral liberalization. Our econometric estimations consider impacts on both the extensive and intensive margins of trade. The reduced tariffs imposed on emerging countries have contributed to growth in their exports of differentiated goods at the intensive margin; they have not affected the probability of recording new flows. Growth in emerging countries' exports at the extensive margin of trade has been due mainly to an upward shift in their comparative advantage and improvements to their infrastructure.

\section{Keywords}

Tariffs, trade liberalization, emerging countries, margins of trade

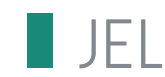

F13; F15 


\title{
Tariff Liberalization and Trade Integration of Emerging Countries
}

\author{
Anne-Célia Disdier, Lionel Fontagné \& Mondher Mimouni
}

\section{Introduction}

This paper examines how emerging economies' exports have been affected by the most recent episode of large scale trade liberalization resulting from the last successful round of multilateral negotiations - the Uruguay Round - and continuous expansion of bilateral agreements. The Uruguay Round was implemented in the ten years 1995-2005, i.e. in a period when several developing countries emerged. The Uruguay Round was concluded in Marrakech in April 1994 following seven and a half years of negotiation. The 123 signatory countries established the World Trade Organization (WTO), and concluded the most ambitious multilateral agreement since the GATT 1947 (General Agreements on Tariffs and Trade), which covered numerous issues such as tariffs, non-tariff measures, tropical products, anti-dumping, subsidies, intellectual property, trade related investment measures, dispute settlement mechanisms, and services. Tariffs on industrial goods were reduced by $40 \%$ and the two sectors consigned to the fringes of the multilateral system - agriculture and textile and clothing - were reintegrated within the normal discipline of the multilateral trade system. The Uruguay Round also reduced tariff escalation. ${ }^{2}$ The conclusions of the agreement were enforced for tariffs on goods for a five year period starting January 1, 1995. For agriculture, the implementation period for the country-specific commitments was six years for developed countries. In accordance with the Special and Differential Treatment principle, developing countries were allowed up to 10 years for implementation of their commitments. In addition, with the termination on January 1, 2005 of the 10-year transitional Agreement on Textiles and Clothing (ATC) which substituted for the bilateral quotas negotiated under the Multifiber Arrangement (1974-94), quantitative restrictions in the textile sector were removed.

\footnotetext{
We are deeply indebted to Xavier Pichot for his help in constructing our raw dataset of tariffs. We thank participants at ETSG 2011, FREIT-EITI 2013, RIEF 2013, CEPII seminar and Geneva Trade and Development Workshop for helpful comments. Part of this research was funded by the Agence Nationale de la Recherche (ANR), under grant ANR-12JSH1-0002-01.

A-C. Disdier: Paris School of Economics, Inra, Paris; L. Fontagné: Paris School of Economics (Université Paris 1) and CEPII, Paris (correspondence: lionel.fontagne@cepii.fr); M. Mimouni: ITC (UNCTAD -WTO), Geneva.

1 More precisely, $40 \%$ for developed countries, 37\% developing countries and $25 \%$ least developed countries.

2 Tariff escalation occurs when tariffs increase with the value added in the final product, e.g. tariffs are higher on canned fruits than on fresh fruits.

3

A large body of literature examines ex ante what might be the outcome of the Round (e.g. Harrison et al., 1997) based on a sectoral CGE approach and focusing on overall welfare gains. Here we adopt an ex post approach which does not limit our investigation to the effects of the Round per se but includes the impact of the tariff cuts more generally whether multilateral, bilateral or even unilateral.
} 
Thus, the Uruguay Round - and the related period of intense tariff dismantling more generally - provides a good case to study multilateral and comprehensive reductions in trade barriers at world level. It is especially interesting since during the period of implementation of the agreement, the rapid emergence of new players on world markets profoundly reshaped trade patterns.

To what extent tariff dismantling contributed to the emergence of new super traders such as China, and to a surge in exports from emerging countries more generally, remains an open question. Apart from tariff cuts, other determinants may have played a role, including the economic growth of importers and exporters, the upward shift in the comparative advantage of exporters associated with their Gross Domestic Product (GDP) per capita growth, the drastic reductions in transport costs due to containerization, and the development of global value chains (Yi, 2003; Hanson, 2012).

If we focus only on the actions taken by the WTO, other dimensions such as the set of rules providing multilateral trade discipline and the accession of new members may have played a role. ${ }^{4}$ Similarly if we focus on tariffs, not everything relies in tariff cuts. By binding their tariffs, WTO members offer market access security to potential exporters, which affects individual firms' market entry decisions. ${ }^{5}$ This reduced uncertainty is expected to have a positive impact on the extensive margin of trade (Francois and Martin, 2004). Sala et al. (2010) find clear theoretical evidence of this mechanism in a heterogeneous firm framework, and present a numerical simulation of how market access responds to cuts in bound rates even in presence of a binding overhang.

In the case of emerging countries, we examine the extent to which cuts in the applied tariffs faced on exporting markets led to zero trade flows turning positive (the extensive margin), and the impact on the value of existing export flows (the intensive margin). These margin definitions are similar to those usually applied in the trade literature (see e.g. Besedeš and Prusa, 2011). ${ }^{6}$ The period 1995-2005 corresponds to full implementation of the Uruguay Round agreement. However, our analysis starts in 1996 because tariff data are available from 1996 in the Harmonized System (HS) classification of traded products, and for the whole 1996-2006 period. We include 2006 to ensure that we fully observe the impact of this episode of trade liberalization. Note that negotiations lead to commitments on bound tariffs

\footnotetext{
4 Rose (2004) argues that WTO membership has no effect on trade but takes no account of the shift from zero to positive trade flows - the so-called extensive margin of trade. These new flows correspond to new products shipped by incumbent exporting countries to a given destination market or by countries exporting for the first time to a given market. Accounting for this margin and using aggregated flows, Felbermayr and Kohler (2010) find that belonging to the WTO makes a difference for countries that otherwise would never have traded bilaterally.

Tariff binding is the commitment to not increasing a tariff in the future without accompanying compensation offered to trade partners. Tariffs can be bound at above the currently applied tariff, in which case there is a binding overhang.

${ }^{6}$ Cheptea et al. (2010) consider all trade flows except intra-EU trade and mineral, specific, and non-classified products, and show that in 1994 only $4.5 \%$ of potential trade flows at the HS 6-digit level were observed, and in $20075.9 \%$. Using HS6 export flows for 126 exporting countries to 59 importing countries in 1995, Hummels and Klenow (2005) find that the extensive margin of trade accounts for more than $60 \%$ of the increased exports of larger economies. However, the link between export development and new flows is not systematic, as stressed by Amiti and Freund (2010) in the Chinese case.
} 
which might be higher than applied tariffs: the actual reductions in tariffs may ultimately be smaller than suggested by the evidence on the Uruguay Round commitments.

We find a limited impact on emerging countries' exports of tariff cuts between 1996 and 2006. At the extensive margin, the effects are not significant, meaning that diversification of emerging countries' exports was not driven by tariff cuts. At the intensive margin, tariff cuts have had visible impact but only on exports of differentiated goods. On the other hand, our estimations show that other factors played a major role in the expansion of emerging countries' exports. Increases in GDP per capita between 1996 and 2006 (in both current dollars and in purchasing power parity - PPP) had a major influence, mirroring the shift in comparative advantage and infrastructure improvements in emerging countries. All these changes occurred under the umbrella of WTO discipline on market access if not through tariff cuts.

This paper adds to the literature by using highly disaggregated data for a large sample of countries over a sufficiently long time span to observe the cumulated impacts of a complete episode of multilateral trade liberalization and the development of free trade areas (FTAs). ${ }^{7}$ Kehoe and Ruhl (2013) consider bilateral trade at the 5-digit level of the Standard International Trade Classification (SITC) of products (i.e. 1,836 products) for country pairs engaged in episodes of large-scale trade liberalization. Their results show that changes in the extensive margin of trade are large for many of these episodes. Furthermore, the authors highlight that the extensive margin of trade is hardly influenced by the business cycle. Using bilateral trade data for 90 countries and 137 partners in 2005 from the Comtrade database, and tariffs from the Trade Analysis and Information System (TRAINS) database, Flam and Nordstrom (2007) compute gravity equations to explain the extensive and intensive margins. They find that tariffs represent significant barriers to trade but due to their limited crosssection data, they were not able to investigate the impact of variations in tariff times. Relying on a 7-digit product classification, Feenstra and Kee (2007) find a positive impact of United States (US) tariff reductions associated with the NAFTA on the diversification of Mexican exports. They find a $20 \%$ increase in exported variety due to the NAFTA. But what is specific to tariff cuts and what is associated with the indirect effects of economic integration (e.g. transfer of technology, foreign direct investments) remains unclear. Hence, a larger set of experiences of trade liberalization is required. Debaere and Mostashari (2010) rely on the US HS-10 digit classification (comprising some 22,000 different product categories although only half of these were traded continuously throughout the period considered), and US HS-8 tariff data. They examine to what extent US tariff reductions led to increased diversity of imports over the period 1989 to 2000; they find a positive but very limited effect. Finally, the impact of the Uruguay Round on trade margins is investigated in Buono and Lalanne (2012) using individual firm data for France. They consider 147 destinations and 57 sectors and observe a positive effect of tariff cuts on the intensive margin but find no evidence of an impact on the

\footnotetext{
7 Using aggregated data, Baier and Bergstrand (2001) find that two-thirds of the observed trade growth in the period 1958-60 to 1986-88 is due to GDP growth and only a quarter is the result of tariff reductions. The aggregate evidence is driven partly by new trade flows.
} 
extensive margin. Note that since their paper uses firm data, the margins are defined differently.

In contrast to previous work, we rely on detailed trade data and tariff information for a large set of importers and exporters. We focus on emerging economies' exports, the most dynamic part of world trade, and consider a time window covering the most recent episode of multilateral trade liberalization. ${ }^{8}$ In order not to overstate the role of tariff cuts, we consider applied (Most Favored Nation - MFN - and preferential) rather than bound tariffs. Cuts to bound tariffs may be impressive but often have limited impact on applied tariff due to binding overhang. Part of the exercise consists of reconstructing a detailed database of applied tariffs for 1996 using the same method as for 2006, taking stock of tariff preferences, tariff quotas (put in place in the Uruguay round) and specific tariffs. Calculations were made at tariff line level using the MAcMap method (cf. infra) and aggregated to the HS6 level, which is the classification of trade flows. The mechanism linking liberalization and trade which is what we are interested in, goes from applied tariffs to both the extensive and intensive margins of trade.

The rest of the paper is organized as follows. Section 2 presents the data and some descriptive statistics. Section 3 explains the econometric specification and Section 4 discusses the results. Section 5 concludes.

\section{Data and descriptive statistics}

\subsection{Sources and sample}

The value added of this paper is to address the above discussed issues relying on a large sample of countries at the most detailed possible product classification level. This comes at a cost: it requires us to use a product classification that is common to the whole sample of countries, which cannot be the country specific tariff line level. Currently, the most disaggregated level common to all countries is the HS6 classification.

We combine two datasets: trade and tariffs at the HS6 level. Regarding trade flows, the BACI (Base pour l'Analyse du Commerce International) database provides exhaustive reconciled trade flows at the HS6 level since 1995. Export values are free on board and equal to the corresponding import values. The reconciliation method follows Gaulier and Zignago (2010).

Currently, the main source of information on tariffs for analytical studies is WITS (World Integrated Trade Solution), the World Bank statistics portal. WITS comprises data from the WTO Integrated Data Base (IDB) and WTO Consolidated Tariff Schedules (CTS), and from TRAINS (United Nations Conference on Trade and Development - UNCTAD Trade Analysis and Information System). TRAINS relies on the United Nations Tariff and Market Access Database (TARMAC) developed by UNCTAD and UNCTAD-WTO International Trade Centre

8

Considering several exporters makes it impossible to rely on individual firm data. 
(ITC). The second source of information is MAcMap (ITC), which relies on TARMAC, IDB and CTS. MACMap provides consistent treatment of trade preferences and computation of ad valorem equivalents (AVEs) of specific tariffs (Bouët et al., 2008). We combine these sources of information to obtain a detailed database relying on a common methodology, as described in Figure 1.

Figure 1. Combination of data sources on tariffs

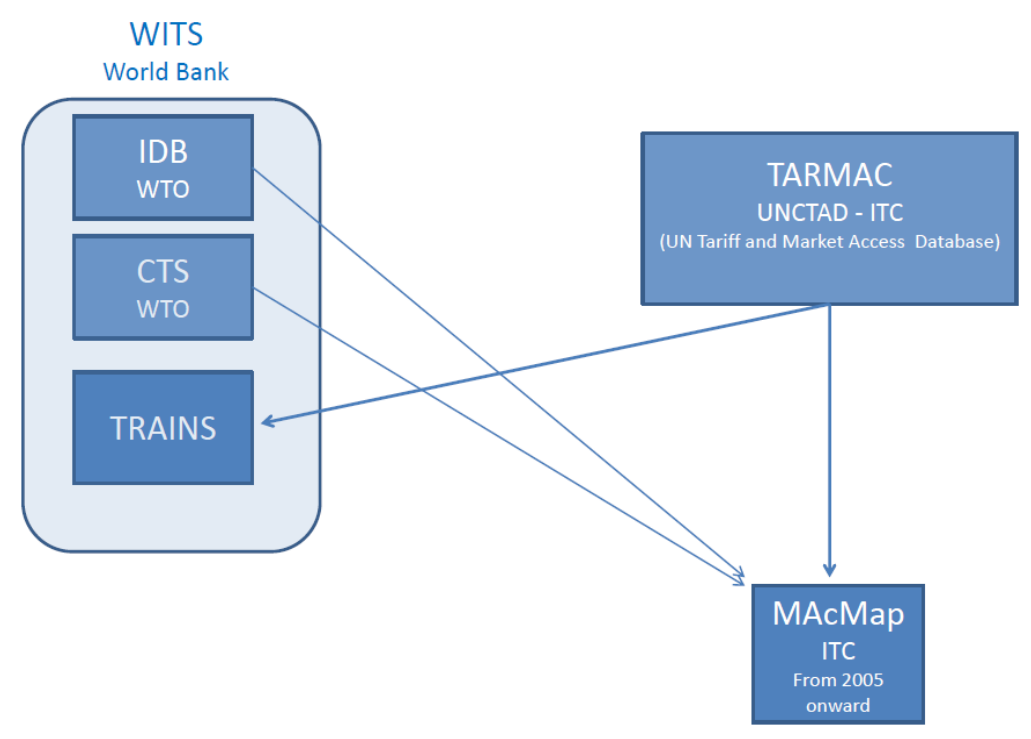

The construction of our dataset, which differs from TRAINS, is part of the value added of our paper. It also differs slightly from the HS6 version of MAcMap used extensively in the literature. Firstly, where available, we rely on tariff line instead of HS6 information to compute tariff equivalents. This ensures greater accuracy of unit value treatment because we reduce the usual aggregation bias (two tariff lines with very different unit values averaged within an HS6 position). However, the main difference is that we reconstruct a MAcMap type base for a year prior to 2001; the beta version of MAcMap was published in $2001 .{ }^{10}$ As already mentioned, we chose 1996. We proceed as follows.

For 1996, we rely on TRAINS source files and apply the MAcMap assumptions and methodology to this source data. ${ }^{11}$ We rely on national tariff schedules at tariff line level in

\footnotetext{
9 See http://www.cepii.fr/anglaisgraph/bdd/baci.htm for BACI. MAcMap is disseminated on-line on the ITC website (www.intracen.org). The HS6 version commonly used in the literature is on the CEPII (Centre d'Etudes Prospectives et d'Informations Internationales) website.

See Bouët et al. (2001) for a description of the beta version of MAcMap.

If a country is missing in TRAINS, we use IDB instead.
} 
order to better measure the unit values of trade flows. ${ }^{12}$ The richness of the tariff line is worth considering for computation of AVEs of non-ad valorem tariffs and for the treatment of tariff quotas. $^{13}$ The method used here is mostly similar to that applied in the WTO World Trade Profile, ${ }^{14}$ with some slight differences. ${ }^{15}$ Our exercise is conducted at the HS6 level of the product classification, and tariffs at the HS6 level are computed as a simple average of the tariffs in the tariff lines of every country (in order to neutralize the impact of differences in the structure of schedules beyond the 6-digit level).

Our empirical analysis focuses on the bilateral exports of emerging countries to the ir main importers. As yet there is no consensus on either the definition of "emerging economies" or the list of countries included in that group. Therefore we rely on the classifications provided by six institutions (International Monetary Fund, UNCTAD, CEPII, Morgan Stanley Capital International, London Stock Exchange and the G20 group) and consider a country is an emerging country if it is classified as such by at least three of these six institutions. The Boao Forum for Asia in its 2009 annual report provides a list of countries defined as "emerging" by each of these institutions (Boao Forum for Asia, 2010). Our sample includes 18 emerging exporters: Argentina, Brazil, Chile, China, Colombia, Egypt, India, Indonesia, Malaysia, Mexico, Pakistan, Peru, the Philippines, Russia, South Africa, South Korea, Thailand, and Turkey.

In relation to importers, our sample includes all main partners of the emerging countries, and covers $75 \%$ of world exports of emerging countries in 2006. We consider two groups of importing countries: i) advanced countries (Australia, Canada, Switzerland, EU15, Japan, Norway, USA), and ii) new advanced and new industrialized countries (Argentina, Brazil, Chile, China, India, Indonesia, Israel, Malaysia, Mauritius, Mexico, the Philippines, Singapore, South Africa, South Korea, Sri Lanka, Turkey, Venezuela, and Vietnam). We run separate estimations for each group of importers. Our country division may present some disadvantages since the boundary between the groups may be very narrow for some countries. However, the grouping is based on several criteria (not a single standard such as per capita income), and the use of a definite divide allows us to analyze trade trends over time.

\footnotetext{
12

In principle, median unit values are computed for each importer and product. When the distribution of unit values does not allow such an approach we adopt a tiered approach by partitioning the distribution and averaging the center unit values in each tier. When too few observations are available (less than 10 for an importer and a tariff line) this algorithm cannot be used and we use the HS6 unit value instead. It is computed as the unit value of the reference group to which the country belongs. Reference groups are constructed using Principal Component Analysis.

Non-ad valorem tariffs are comprised of specific duties, compound duties, mixed duties and technical duties, all defined at tariff line level. They are imposed by 68 out of the 151 countries covered in MAcMap. Interestingly, the products thus protected are often very sensitive products with high levels of protection, and therefore potentially associated with many bilateral zero flows. In total, 28,000 tariffs in MAcMap are of this type, of which 15,000 were treated at tariff line level.

14

15 http://stat.wto.org/

The first difference is that when computing the AVEs of specific tariffs we rely on 3-year moving averages of unit values; we also introduce a $1,000 \%$ cap (less than 200 observations).
} 
To combine tariff and trade data successfully, we have to make few choices/assumptions. In different years, and for different importing countries, tariff data are expressed in different versions of the HS classification. We used conversion tables to convert all the series into HS 1992. Where more than one tariff position was available for a given year, HS6 product, and importing and exporting countries, we took the average. Our final sample includes 4,870 HS6 products present in 1996 and 2006.

\subsection{Descriptive statistics}

Figure 2 provides export values and number of product-destination categories exported by each emerging country to the set of importers and for the products included in our sample. Comparison of 1996 and 2006 observations indicates a net increase on both dimensions (flows and values) for each emerging exporter. Thus, we need to disentangle the impact of tariff cuts on the two dimensions of trade expansion.

Figure 2. Export Value and Product-Destination Flows

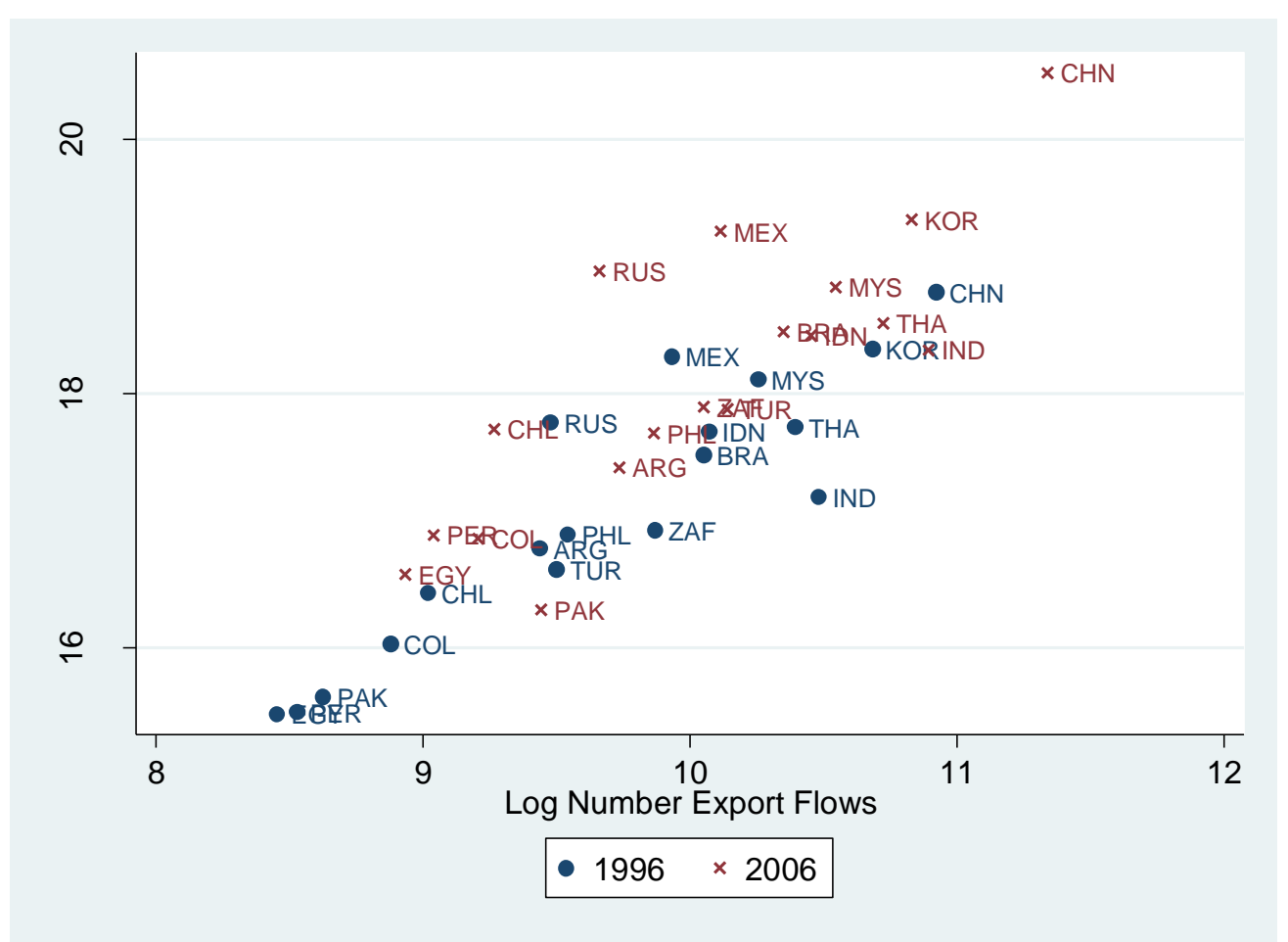

Note: Each observation is an emerging exporting country. 'Number Export Flows' is the number of product-destination categories exported by an emerging country. (Max. number of products: 4870; Max. number of destinations: 24 or 25 depending whether the emerging country is also included as importer in our sample). 'Export Value' is the value that an emerging country exports to the (24 or 25) importing countries included in our sample. 
Table 1 presents the applied tariff cuts during the period of trade liberalization associated with implementation of the Uruguay Round. Not all these cuts are associated with the Round however: certain countries (e.g. India) would likely have cut their tariff unilaterally over that period. Table 1 reports the simple average tariffs computed for the 4,870 HS products included in our sample and applied by each importer to its imports from emerging countries in 1996 and 2006. For all importers (except Japan where we observe a slight increase mainly related to specific tariffs), we observe a significant decrease in the average tariff over the decade considered. As expected, the average tariffs applied by new advanced and new industrialized importers (14.67\% in 1996 and 8.46\% in 2006) are higher than the average tariffs applied by advanced countries (4.87\% in 1996 and $3.22 \%$ in 2006). However, the decrease in these averages observed between 1996 and 2006, is higher for new advanced/industrialized countries than for advanced economies. For advanced importers, the average tariff was low in 1996 and the percentage changes in protection correspond to trivial absolute changes in the mean. Table 1 also reports standard deviation. There are significant differences among importers in terms of tariff dispersion; In 2006, South Korea, Malaysia, Norway and Turkey show the highest dispersion rates. Finally, Table 1 presents the share of tariff peaks, i.e. tariffs above $15 \%$. Here, also, we observe significant variation across countries, but for all (except South Africa) the share decreases between 1996 and 2006. However, for seven countries (Argentina, Brazil, Mexico, South Africa, Sri Lanka, Venezuela, and Vietnam) it remains above $25 \%$ in 2006.

Did emerging countries benefit from lower tariffs and higher tariff cuts between 1996 and 2006, than other groups of exporters? The average tariffs faced by emerging countries are in line with those faced by other exporters. In advanced markets, emerging countries faced an average tariff of $4.9 \%$ in 1996, while other developing and least developed countries (DCs and LDCs) were faced with slightly lower average tariffs (4.5\% in 1996) due to tariff reductions and exemptions granted as part of the development policy. Advanced countries faced higher tariffs (5.6\% in 1996). All groups of exporters experienced tariff cuts between 1996 and 2006, but emerging countries faced the smallest reduction (1.7 percentage points), while the cuts for other DCs and LDCs are equal to 2 percentage points, and to 1.8 percentage points for advanced countries. In new advanced and new industrialized markets, the differences in average tariffs and cuts over the 1996-2006 period between groups of countries are again rather small. In 1996 (resp. 2006), average tariffs are 14.5\% (8.2\%) for imports from advanced countries, $14.7 \%$ (8.5\%) for imports from emerging countries and $14.7 \%(9.3 \%)$ for those from DCs and LDCs. 
Table 1. Average tariffs on imports from emerging countries (\%)

\begin{tabular}{|c|c|c|c|c|c|c|}
\hline \multirow[b]{2}{*}{ Importing countries } & \multicolumn{3}{|c|}{1996} & \multicolumn{3}{|c|}{2006} \\
\hline & $\begin{array}{c}\text { Mean } \\
(\%)\end{array}$ & $\begin{array}{c}\text { Std. } \\
\text { deviation }\end{array}$ & $\begin{array}{c}\text { Share of } \\
\text { tariff peaks } \\
(\%)\end{array}$ & $\begin{array}{c}\text { Mean } \\
(\%)\end{array}$ & $\begin{array}{c}\text { Std. } \\
\text { deviation }\end{array}$ & $\begin{array}{c}\text { Share of } \\
\text { tariff peaks } \\
(\%)\end{array}$ \\
\hline All importing countries & 11.85 & $(22.54)$ & 28.0 & 6.95 & $(16.84)$ & 14.9 \\
\hline Advanced & 4.87 & (14.76) & 8.4 & 3.22 & (13.34) & 4.2 \\
\hline Australia & 5.47 & $(9.15)$ & 11.5 & 3.26 & $(4.67)$ & 4.1 \\
\hline Canada & 5.75 & (12.37) & 11.3 & 3.21 & (10.56) & 6.2 \\
\hline EU15 & 4.33 & $(9.57)$ & 3.8 & 2.61 & $(9.01)$ & 3.6 \\
\hline Japan & 2.91 & (9.93) & 4.3 & 3.34 & (12.83) & 3.7 \\
\hline Norway & 9.13 & (29.24) & 16.5 & 4.85 & $(25.00)$ & 5.3 \\
\hline Switzerland & 3.51 & (13.45) & 5.6 & 3.19 & (14.54) & 4.6 \\
\hline United States & 3.00 & $(5.87)$ & 5.6 & 2.05 & $(5.03)$ & 2.2 \\
\hline $\begin{array}{l}\text { New advanced/ } \\
\text { industrialized }\end{array}$ & 14.67 & (24.44) & 35.9 & 8.46 & (17.85) & 19.2 \\
\hline Argentina & 12.08 & $(5.75)$ & 36.4 & 11.56 & (14.07) & 26.8 \\
\hline Brazil & 12.41 & (5.73) & 36.9 & 10.00 & (6.93) & 26.9 \\
\hline Chile & 10.97 & $(0.53)$ & 0.0 & 4.10 & (2.68) & 0.0 \\
\hline China & 17.48 & (12.34) & 52.2 & 9.51 & (8.99) & 18.6 \\
\hline India & 38.67 & (18.40) & 90.1 & 14.21 & (13.42) & 14.5 \\
\hline Indonesia & 12.43 & (14.32) & 41.0 & 6.10 & $(9.68)$ & 12.2 \\
\hline Israel & 9.51 & (49.49) & 8.5 & 5.57 & (12.97) & 4.6 \\
\hline Malaysia & 10.24 & (32.93) & 30.6 & 7.43 & (25.22) & 20.0 \\
\hline Mauritius & 28.90 & (25.87) & 76.8 & 3.41 & (9.53) & 13.2 \\
\hline Mexico & 14.69 & (13.70) & 46.8 & 11.80 & (9.81) & 36.8 \\
\hline Philippines & 14.40 & (11.03) & 45.3 & 5.46 & (6.06) & 12.8 \\
\hline Singapore & 0.02 & $(1.36)$ & 0.0 & 0.02 & (1.16) & 0.0 \\
\hline South Africa & 8.92 & (18.64) & 20.2 & 8.07 & (12.20) & 27.0 \\
\hline South Korea & 13.46 & (47.63) & 8.2 & 12.38 & (48.33) & 8.1 \\
\hline Sri Lanka & 20.30 & (27.67) & 46.8 & 11.51 & (20.24) & 42.9 \\
\hline Turkey & 10.76 & (21.62) & 12.3 & 7.50 & (24.57) & 10.4 \\
\hline Venezuela & 12.46 & (6.09) & 51.5 & 10.31 & $(8.16)$ & 37.4 \\
\hline Vietnam & 16.36 & (18.81) & 42.2 & 13.67 & (17.85) & 33.3 \\
\hline
\end{tabular}

Note: For the 4,870 products included in our sample. Tariff peaks are defined as tariffs above $15 \%$.

We next turn to trade flows and investigate the variation in exports from emerging countries between 1996 and 2006. We examine both the extensive and intensive margins of trade. Table 2 provides aggregated results for the extensive margin of trade; Table 3 breaks these results down into product-destination dimensions by exporters.

The results show an increase in trade at the extensive margin. We observe first the diversification of emerging countries' exports at the product and product-country levels. Table 2 shows that the average number of HS products exported by emerging countries between 
1996 and 2006 increased by $10.4 \%$ for exports to advanced countries, and by $12.8 \%$ for exports to new advanced and new industrialized countries. This growth is more impressive if we focus on the product-destination dimension. While the number of positive flows still represents less than $24 \%$ of total potential flows, this share increased significantly by $39.6 \%$ between 1996 and 2006. The increase is even larger if we consider only exports to new advanced and new industrialized countries (i.e. 51.1\%). All in all, these results mean that emerging countries sent existing export products to many more destinations, suggesting that trade costs reduced over the period considered.

Second, all emerging countries registered some diversification of their exports. Table 3 suggests a rise in the number of positive export flows, i.e. in the number of productdestination categories served by each emerging exporter. The highest increases are observed for Turkey $(+89.2 \%)$ and Pakistan $(+126.1 \%)$. For all emerging exporters, the contribution of new advanced and new industrialized markets to this growth is larger than the contribution of advanced markets. The relative importance of new advanced and new industrialized markets in non-zero trade flow growth is particularly high for Asian countries.

Table 2. Extensive margin of emerging countries exports

\begin{tabular}{|c|c|c|c|c|}
\hline & \multirow{2}{*}{$\begin{array}{l}\text { Potential } \\
\text { number }\end{array}$} & \multicolumn{3}{|c|}{ Effective number } \\
\hline & & 1996 & 2006 & Variation (\%) \\
\hline \multicolumn{5}{|l|}{ Product dimension } \\
\hline \multicolumn{5}{|c|}{ 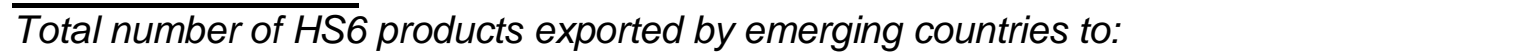 } \\
\hline Advanced countries & 4,870 & 4,859 & 4,863 & 0.08 \\
\hline New advanced/industrialized countries & 4,870 & 4,858 & 4,864 & 0.12 \\
\hline \multicolumn{5}{|c|}{ Average number of HS6 products exported by emerging countries to: } \\
\hline Advanced countries & 4,870 & $3,054.9$ & $3,372.4$ & 10.4 \\
\hline New advanced/industrialized countries & 4,870 & $2,872.4$ & $3,240.3$ & 12.8 \\
\hline \multirow{2}{*}{\multicolumn{5}{|c|}{$\begin{array}{l}\text { Product-destination dimension } \\
\text { Total number of product-destination categories exported by emerging countries } \\
\text { (non-zero trade): }\end{array}$}} \\
\hline & & & & \\
\hline Total & $2,133,060$ & 366,501 & 511,774 & 39.6 \\
\hline Advanced countries & 613,620 & 159,134 & 198,368 & 24.7 \\
\hline New advanced/industrialized countries & $1,519,440$ & 207,367 & 313,406 & 51.1 \\
\hline
\end{tabular}

Note: For the 4,870 products included in our sample 
Table 3. Extensive margin of trade detailed by exporting country

\begin{tabular}{|c|c|c|c|}
\hline & \multirow[t]{2}{*}{$\begin{array}{c}\text { 1996-2006 variation in the } \\
\text { number of positive export } \\
\text { flows (product-destination) (\%) }\end{array}$} & \multicolumn{2}{|c|}{$\begin{array}{l}\text { Contribution of each group of } \\
\text { importing countries to 1996-2006 } \\
\text { variation (percentage points) }\end{array}$} \\
\hline & & $\begin{array}{c}\text { Advanced } \\
\text { countries }\end{array}$ & $\begin{array}{l}\text { New advanced/ } \\
\text { industrialized } \\
\text { countries }\end{array}$ \\
\hline All exporters & 39.6 & 10.7 & 28.9 \\
\hline Argentina" & 34.6 & 14.1 & 20.5 \\
\hline Brazil $^{\#}$ & 34.8 & 11.8 & 23.0 \\
\hline Chile & 28.0 & 13.8 & 14.2 \\
\hline China $^{\#}$ & 51.6 & 10.5 & 41.1 \\
\hline Colombia & 38.6 & 18.5 & 20.1 \\
\hline Egypt & 61.4 & 24.4 & 37.0 \\
\hline India" & 50.6 & 12.3 & 38.3 \\
\hline Indonesia" & 46.2 & 10.8 & 35.4 \\
\hline Malaysia\#" & 33.7 & 4.9 & 28.8 \\
\hline Mexico" & 19.6 & 6.0 & 13.6 \\
\hline Pakistan & 126.1 & 51.3 & 74.8 \\
\hline Peru & 67.0 & 27.5 & 39.5 \\
\hline Philippines ${ }^{\#}$ & 37.6 & 9.3 & 28.3 \\
\hline Russia & 19.9 & 5.7 & 14.2 \\
\hline South Africa & 19.6 & 6.9 & 12.7 \\
\hline South Korea & 15.8 & 4.0 & 11.8 \\
\hline Thailand & 39.0 & 8.2 & 30.8 \\
\hline Turkey & 89.2 & 27.2 & 62.0 \\
\hline
\end{tabular}

Note: For the 4,870 products included in our sample. " denotes Emerging countries that are both exporters and importers in our sample.

Tables 4 and 5 provide statistics for the intensive margin of trade. The results underline a strong increase in trade at the intensive margin. Table 4 highlights how world exports from emerging countries multiplied more than three-fold between 1996 and 2006 and that these exports were reoriented slightly toward other emerging markets: the share exported to advanced countries decreased slightly (from $56.9 \%$ to $54.0 \%$ ), while the share exported to new advanced and new industrialized countries rose (from 19.0\% to 20.0\%). Furthermore, the share of emerging countries exports in imports of both advanced countries and new advanced/industrialized countries increased by around 10 percentage points between 1996 and 2006. All emerging exporters registered an increase in their exports at the intensive margin between 1996 and 2006 (Table 5). Growth rates are large (all above 58\%) or very large (for 7 countries they are over $100 \%$ with a maximum of $445.9 \%$ for China). The two last columns in Table 5 show that this increase is related mainly to trade with advanced countries rather than exports to new advanced and industrialized countries (146.7\% vs. $56.9 \%$ for the whole sample). It is interesting that for Mexico and Turkey, advanced countries contribute to almost all the increase, which is to be expected given the regional integration of these countries with the US and Canada respectively under the NAFTA, and with the EU. For five 
countries, the contribution of exports to new advanced and new industrialized countries is bigger than the contribution of exports to advanced countries. Four of these are Asian countries (Indonesia, Malaysia, Philippines, South Korea), suggesting that regional integration in Asia is more effective than in other emerging regions (such as Latin America).

Table 4. Intensive margin of emerging countries exports

\begin{tabular}{lcccc}
\hline & \multicolumn{3}{c}{ Importers } \\
& Advanced countries & \multicolumn{2}{c}{$\begin{array}{c}\text { New advanced/ } \\
\text { industrialized } \\
\text { countries }\end{array}$} \\
& 1996 & 2006 & 1996 & 2006 \\
Bilateral trade (millions USD) & 553,910 & $1,637,698$ & 185,016 & 605,734 \\
$\begin{array}{c}\text { Share that this bilateral trade represents: } \\
\quad \text { In world exports of emerging countries (\%) }\end{array}$ & 56.9 & 54.0 & 19.0 & 20.0 \\
$\quad$ In world imports of importing countries (\%) & 25.1 & 35.1 & 20.6 & 29.2 \\
\hline
\end{tabular}

Note: For the 4,870 products included in our sample. 2006 sample is restricted to trade relationships that were present in 1996.

Table 5. Intensive margin of trade detailed by exporting country

\begin{tabular}{lccc}
\hline & $\begin{array}{c}\text { 1996-2006 variation in } \\
\text { bilateral trade } \\
(\%)\end{array}$ & $\begin{array}{c}\text { Contribution of each group of } \\
\text { importing countries to 1996-2006 } \\
\text { variation (percentage points) } \\
\text { Advanced } \\
\text { countries }\end{array}$ & $\begin{array}{c}\text { New advanced/ } \\
\text { industrialized } \\
\text { countries }\end{array}$ \\
\hline All exporters & & 146.7 & 56.9 \\
Argentina\# & 203.6 & 17.9 & 40.4 \\
Brazil & 58.3 & 84.7 & 51.7 \\
Chile & 136.4 & 151.2 & 69.4 \\
China & 220.6 & 347.9 & 98.0 \\
Colombia & 445.9 & 71.6 & 28.0 \\
Egypt & 99.6 & 56.5 & 19.2 \\
India & 75.7 & 119.7 & 67.8 \\
Indonesia & 187.5 & 46.2 & 46.8 \\
Malaysia\# & 93.0 & 45.2 & 54.6 \\
Mexico & 99.8 & 160.2 & 3.2 \\
Pakistan & 163.4 & 62.6 & 7.7 \\
Peru & 70.3 & 185.6 & 46.3 \\
Philippines & 231.9 & 42.6 & 61.0 \\
Russia & 103.6 & 177.0 & 40.7 \\
South Africa & 217.7 & 121.7 & 14.3 \\
South Korea & 136.0 & 76.9 & 91.7 \\
Thailand & 168.6 & 57.3 & 49.4 \\
Turkey & 106.7 & 216.0 & 2.7 \\
\hline
\end{tabular}

Note: For the 4,870 products included in our sample. 2006 sample is restricted to trade relationships that were present in 1996. ${ }^{\#}$ denotes Emerging countries that are both exporters and importers in our sample. 
To summarize, descriptive statistics highlight a reduction in the average tariffs affecting emerging countries' exports to their main partners accompanied by a growth in these exports (at both margins). However, these parallel evolutions are not evidence of export development induced by tariff reductions. Our contribution in this paper therefore, is to investigate whether the observed trade expansion results from the observed tariff reduction or whether other factors are at play.

\section{Econometric specification}

Our aim is to estimate the impact on emerging countries' world trade integration of tariff cuts granted by their main trading partners between 1996 and 2006. We decompose the effect for each margin of trade. We investigate whether tariff cuts contribute to the scope of new bilateral trade relationships established between emerging exporters and their main trading partners in 2006 (extensive margin), and to changes in the value of existing export flows between 1996 and 2006 (intensive margin). This imposes use of bilateral applied tariffs.

As the descriptive statistics show, the main trading partners of emerging countries constitute a heterogeneous group (advanced countries vs. new advanced and new industrialized countries; see appendix for the list of countries). Accordingly, we split our sample into two sub-samples and run our estimations separately for each group of partners.

\subsection{Extensive margin of trade}

We follow the approach developed by Debaere and Mostashari (2010), which estimates the impact of tariff reductions between 1989 and 1999 on the range of goods exported to the US in 1999. Our dependent variable, $y_{i j k}$, is the probability of having a new bilateral trade flow in 2006 between countries $i$ and $j$, i.e. the probability that good $k$ (not bilaterally traded in 1996) is exported by the emerging country $i$ to the partner $j$ in 2006. Note that this is equivalent to the probability of a switch from 0 and a new existing flow. $y_{i j k}$ is a binary variable equal to 1 if the good is bilaterally traded in 2006 but not in 1996 and 0 otherwise:

$$
y_{i j k}=1\left[y_{i j k}^{*}>0\right]
$$

where $y_{i j k}^{*}$ is a latent variable. Its value determines whether or not a strictly positive trade flow is observed between $i$ and $j$ on good $k$ in 2006. The value of the latent variable is influenced by several variables. We consider the following explanatory variables:

\footnotetext{
${ }^{16}$ In addition, a Chow test suggests that estimated coefficients differ significantly for the two groups of importers, and confirms this divide.
} 
$\Delta \ln \tau_{i j k} \quad=$ the variation in the logarithm of bilateral tariffs ${ }^{17}$ applied by country $j$ on imports of good $k$ from country $i$ between 1996 and 2006;

$\boldsymbol{X}_{i} \quad=$ a vector of exporter-specific explanatory variables;

$\boldsymbol{X}_{j} \quad=$ a vector of importer-specific explanatory variables;

$\boldsymbol{X}_{i j} \quad=$ a vector of country-pair specific explanatory variables.

The changes in the scope of exports from emerging countries are strongly related to the shift in these countries' comparative advantage. Increased productivity allowed this scope of exported products to increase. The scope of products exported by the North and the South increasingly overlap, though the latter's unit value and market positioning remain different from Northern competitors (Schott, 2004). Productivity changes are reflected in GDP per capita changes, which we use here as a proxy. Thus, we consider the variations in the logarithm of current GDP per capita between 1996 and 2006 as exporter- and importerspecific explanatory variables.

The changes in the scope of products exported by emerging countries may be due also to improvements to their infrastructure. In such cases, GDP per capita based on PPP will be a better proxy than current GDP per capita. We therefore run estimations including the variation in the logarithm of GDP per capita based on PPP (expressed in 2005 USD) between 1996 and 2006 as exporter- and importer-specific explanatory variables.

Size is a third potential explanation for the increased scope of exports by emerging countries. In a Krugman-like world, emerging countries export more products just because they become bigger and offer more varieties. Interestingly, the common perception of a threat from an expanding developing world is based on this assumption. The variables capturing the impact of changes in the sizes of both trading partners are their current populations.

The country-pair specific characteristics capture bilateral trade resistance. We control for bilateral distance - a proxy for variable transport costs. Our data are from the CEPII database.

We also include product-specific fixed effects defined at the HS 6-digit level. These product fixed effects capture product characteristics that are constant over time and not observable. In some specifications, HS6 product fixed effects are interacted with importer fixed effects.

\footnotetext{
As is usual, we consider the power of the tariff $(1+\tau)$ defined as the direct effect of an applied tariff on the duty-paid price of a product. The proportional change in the tariff thus defined is the proportional change in the duty-paid price in the absence of incomplete pass through. See e.g. "Integrated Tariff Analysis System" (ITAS), Australian Productivity Commission, http://www.pc.gov.au/research/economic-models-frameworks/itas2.

http://www.cepii.fr/anglaisgraph/bdd/distances.htm. We tested additional gravity variables such as common language, common border, and colonial links. However, the estimated coefficients of these variables were often non-significant and the results were unaffected by their inclusion.
} 
Finally, we control for the competition faced by emerging countries on their export markets. To do so, we compute a Herfindahl-Hirschman index measuring the concentration of country $j$ 's imports in 1996. This index is calculated by squaring the market share of each exporter $j$ competing on the import market of good $k$ in country $i$, and summing the resulting numbers ( $H_{j k}^{96}=\sum s_{i j k}^{2}$, with $s_{i j k}=M_{i j k} / M_{j k}$ where $s$ is the share and $M$ the value of imports). It is bounded between zero and one: the closer to zero, the more diversified the import basket. Having defined all the variables, we can rewrite our estimated equation as follows:

$$
\begin{aligned}
& y_{i j k}=1\left[y_{i j k}^{*}>0\right] \\
& \left.y_{i j k}^{*}=\beta_{0}+\beta_{1} \Delta \ln \tau_{i j k}+\beta_{2} H_{j k}^{96}+\mathbf{X}_{i}^{\prime} \lambda+\mathbf{X}_{j}^{\prime} \mu+\mathbf{X}_{i j}^{\prime} \varsigma+F E_{k}\right)+\varepsilon_{i j k}
\end{aligned}
$$

Country-pair specific variables (distance) are crude proxies for bilateral trade resistance. Country-pair fixed effects are a better way to properly capture all observable and unobservable characteristics of the bilateral trade relation. Since we have a cross-section dataset, exporter and importer-specific variables are dropped from the estimation (because of collinearity). With country-pair fixed effects and HS6 product fixed effects interacted with importer fixed effects, ${ }^{20}$ our estimated equation becomes:

$$
\begin{aligned}
& y_{i j k}=1\left[y_{i j k}^{*}>0\right] \\
& y_{i j k}^{*}=\beta_{0}+\beta_{1} \Delta \ln \tau_{i j k}+F E_{i j}+F E_{j k}+\varepsilon_{i j k}
\end{aligned}
$$

We estimate the equation using a linear probability model. The inclusion of fixed effects in a probit would give rise to the incidental parameter problem. The linear probability model avoids this issue. A potential drawback of this approach is that predicted probabilities may be outside the unit interval. However, as highlighted by Wooldridge (2002, pp. 456-457), if the set of explanatory variables contains dummies for mutually exclusive and exhaustive categories (which is the case in our specification), the linear probability model is completely general and fitted probabilities outside the unit interval are not a problem. In all regressions, we account for correlation of errors for the same country-pair by appropriate clustering at country-pair level.

\subsection{Intensive margin of trade}

To investigate the effects of tariff cuts on the intensive margin of trade, we use a similar approach. The main difference concerns the dependent variable. Following Bayoumi and Eichengreen (1997) and Baier and Bergstrand (2001), our dependent variable is:

\footnotetext{
${ }^{20}$ Therefore, we have $4,870^{\star} 7=34,090$ HS6 product $X$ importer fixed effects and $18^{\star} 7=126$ country-pair fixed effects for imports by advanced countries from emerging countries, and 4,870*18=87,660 HS6 product X importer fixed effects and $18^{*} 6+17^{\star} 12=312$ country-pair fixed effects for new advanced and new industrialized countries' imports from emerging countries. To keep the number of fixed effects at a reasonable level, we do not interact HS6 product fixed effects and exporter fixed effects.
} 
$\Delta \ln \left(M_{i j k}\right)=$ the changes in the logarithm of the value of bilateral exports of good $k$ from country $i$ to country $j$ between 1996 and 2006.

We focus on the deepening of existing trade relations and consider only trade flows that are strictly positive in both 1996 and 2006. The explanatory variables are the same as those in equation (2). The estimated equation can therefore be written as:

$$
\Delta \ln \left(M_{i j k}\right)=\gamma_{0}+\gamma_{1} \Delta \ln \tau_{i j k}+\gamma_{2} H_{j k}^{96}+\mathbf{X}_{i}^{\prime} \xi+\mathbf{X}_{j}^{\prime} \psi+\mathbf{X}_{i j}^{\prime} \phi+F E_{k}+\eta_{i j k}
$$

If we introduce country-pair fixed effects and HS6 product fixed effects interacted with importer fixed effects, equation (4) becomes:

$$
\Delta \ln \left(M_{i j k}\right)=\gamma_{0}+\gamma_{1} \Delta \ln \tau_{i j k}+F E_{i j}+F E_{j k}+\eta_{i j k}
$$

Equations (4) and (5) are estimated using ordinary least squares (OLS) and the error terms are clustered at country-pair level.

\section{Results}

\subsection{Extensive margin of trade}

Tables 6-9 report the estimation results for the extensive margin of emerging countries' exports. In all estimations, the dependent variable is the probability of recording a new bilateral trade flow in 2006, i.e. the probability that good $k$ is exported from $i$ to $j$ in 2006 but was not exported in 1996. Two sets of importers are considered: i) advanced countries, and ii) new advanced/new industrialized countries (see appendix).

Table 6 presents an overview of the results. Columns (1)-(4) focus on exports from emerging to advanced countries. Column (1) includes only the variation in tariffs as an explanatory variable and HS6 product fixed effects. Columns (2) and (3) control for importer, exporter, and country-pair specific variables. The justification is the path dependency of countries' specialization. Column (2) includes GDP per capita in current dollars for the two trading countries; Column (3) shows GDP per capita based on PPP. Column (4) includes both country-pair fixed effects and product $X$ importer fixed effects. Columns (5)-(8) reproduce the estimations for exports to new advanced and new industrialized countries. We would highlight the following:

- Overall, the variation in tariffs between 1996 and 2006 has no statistically significant effect on the emergence of a new bilateral export flow for good $k$ from an emerging country to its main trading partner in 2006. Recall that we are using applied tariffs and measuring them at product and country-pair level. 
- Regarding exporter specific variables, we observe that population has almost no influence, while the two measures of GDP per capita have a positive and significant effect. Furthermore, GDP per capita in PPP terms has a stronger impact, suggesting that improvements to the infrastructures of emerging countries have a bigger influence on the probability of their exporting good $k$ in 2006 than a shift in their comparative advantage.

- There are some differences across groups of importers. For advanced importers, population has a positive and significant impact, but is not significant for new advanced and new industrialized importers. This positive impact of population simply translates into a size effect. ${ }^{21}$ GDP per capita in current USD and PPP terms for new advanced and new industrialized importers has a positive and significant impact on the export probability of good $k$ from an emerging country to these countries in 2006, contrasting with the negative coefficient of GDP per capita in PPP terms for advanced importers. Accordingly, new export flows from emerging to new advanced and new industrialized countries are also driven by a demand effect.

- Interestingly, the importer's Herfindahl index ${ }^{22}$ is always negative and significant, suggesting that the probability of recording a new bilateral export flow in 2006 between emerging countries and their main trading partners is negatively influenced by the level of concentration of the importing country in 1996: the more concentrated the import market, the lower the probability of a new flow. This competition effect is stronger for exports to advanced countries.

- Last, bilateral distance has a negative and significant impact on the probability of exporting to new advanced/new industrialized countries, while its effect is almost not significant for exports to advanced countries.

These results suggest some initial interpretations. Overall, other things being equal, there is no evidence of a tariff reduction conducive to a broader range of exports from emerging countries in 2006. Economic growth in the emerging countries (proxied by their population) is also not conducive to increased exports, contrary to the common perception in the advanced countries of this "threat". There is an effect from increased income per capita for exporting countries and to a lesser extent importing countries if these latter are new advanced or new industrialized countries. Productivity gains and the shift in comparative advantage towards new activities certainly play a role. Whether inward Foreign Direct Investment fuelled this evolution is beyond the scope of this paper. However, infrastructure improvements appear to

\footnotetext{
21 Recall that our estimations include importer's population and GDP per capita in order to be coherent with the exporters' side which uses GDP per capita to measure the potential shift in comparative advantage or improvements to the infrastructures of emerging countries. The sum of the population and GDP per capita coefficients (which is positive in our estimations) can be considered the GDP effect. Furthermore, current GDP per capita is not significant. 22

If good $k$ is never imported by a country, then it is not possible to compute the Herfindahl index for that country and that product. The number of observations in regressions using the Herfindahl index therefore, is slightly smaller than in other regressions.
} 
have a bigger impact on the expansion in the set of products exported by emerging countries.

Table 7 compares emerging countries with the other set of exporters. It reproduces our preferred estimation (with HS6 product fixed effects interacted with importer fixed effects and country-pair effects) for three alternative samples of exporters: i) emerging countries, ii) an extended group of advanced countries (Australia, Canada, EU15, Japan, Norway, Switzerland and the US, as well as Czech Republic, Estonia, Hungary, Iceland, Israel, New Zealand, Poland, Slovakia and Slovenia), and iii) other developing and least developed countries (DCs and LDCs). For importers, we still consider advanced countries (Australia, Canada, EU15, Japan, Norway, Switzerland and the US) on the one hand, and new advanced and new industrialized countries on the other. We investigate whether the emergence of a new bilateral export flow for good $k$ from country $i$ to country $j$ in 2006 is similarly influenced by the bilateral tariff variation between 1996 and 2006 . 
Table 6. Extensive margin - Basic regressions

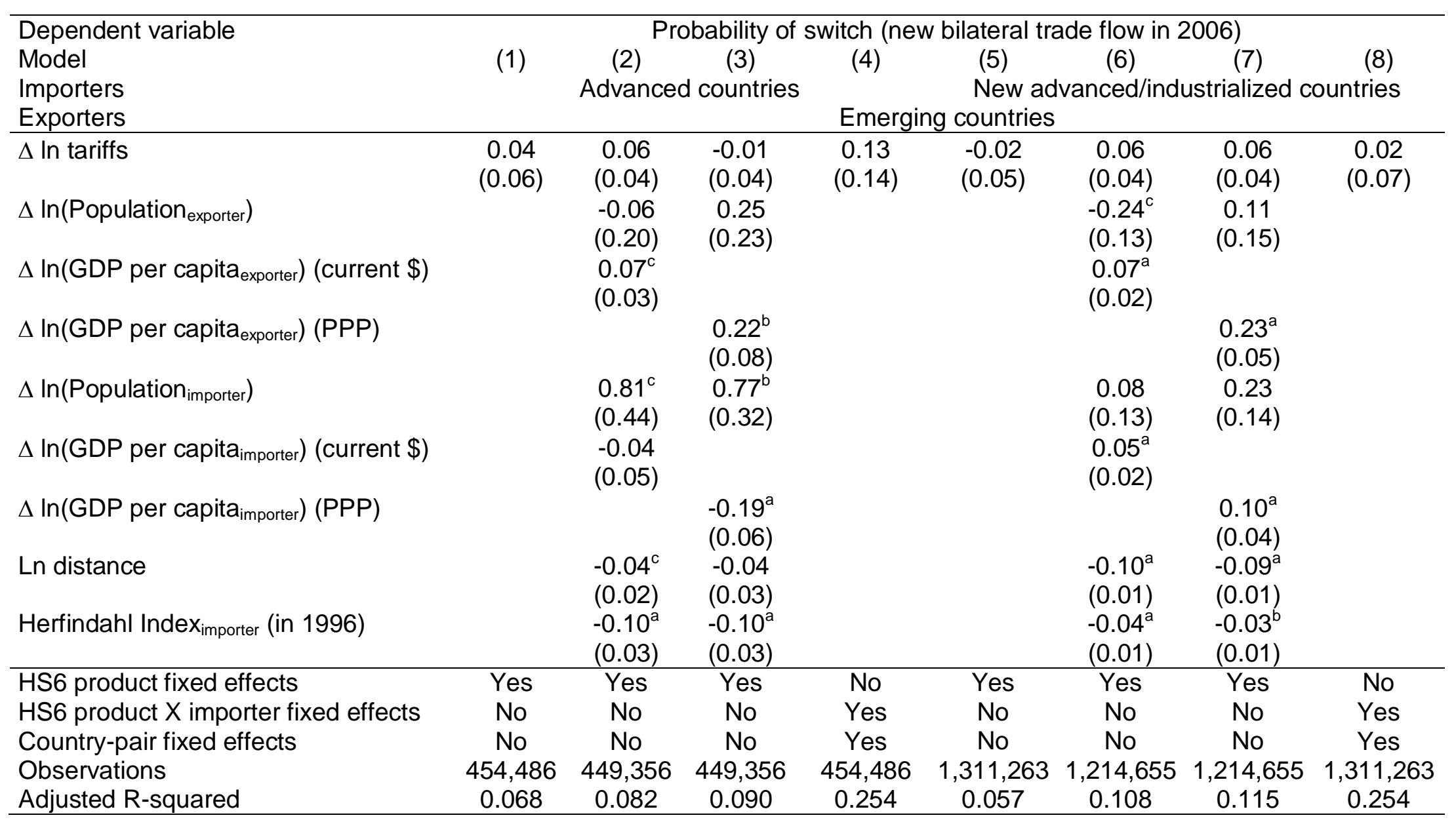

Note: Robust standard errors clustered by country pair in parentheses. Constant \& fixed effects not reported. ${ }^{a} p<0.01,{ }^{b} p<0.05,{ }^{c} p<0.1$. 
Estimated coefficients are hardly significant. However, slight differences appear depending on the selected samples of exporters and importers. For emerging countries, as highlighted in Table 6, new export flows to advanced countries and to new advanced/industrialized countries in 2006 are not influenced by 1996-2006 tariff cuts. In contrast, our results shows that tariff reductions granted by advanced countries (Australia, Canada, EU15, Japan, Norway, Switzerland and the US) between 1996-2006 primarily benefit their mutual trade and bilateral imports from Czech Republic, Estonia, Hungary, Iceland, Israel, New Zealand, Poland, Slovakia and Slovenia, and to a lesser extent to their imports from DCs and LDCs. However, these effects are significant only at the $10 \%$ level. Why we find almost no evidence that tariff reductions imposed by advanced countries on emerging countries, DCs, and LDCs reached their targets, might have several explanations. Non-tariff measures may be substituting for tariff protection. A more positive argument might be related to uncertainty: what matters is the binding coverage, and the tariffs applied by the advanced countries were mostly bound already in 1996. Regarding imports by new advanced and new industrialized countries, estimated coefficients of tariff changes for exports of emerging and advanced countries are not significant (for exports from DCs and LDCs the estimated coefficient is significant at the $5 \%$ level). Again, substituting tariffs by non-tariff measures might explain the lack of significance.

Table 7. Extensive margin - Comparison across groups of exporters

\begin{tabular}{|c|c|c|c|c|c|c|}
\hline Dependent variable & \multicolumn{6}{|c|}{ Probability of switch (new bilateral trade flow in 2006) } \\
\hline Model & (1) & $(2)$ & $(3)$ & $(4)$ & $(5)$ & (6) \\
\hline Importers & \multicolumn{3}{|c|}{ Advanced countries } & \multicolumn{3}{|c|}{$\begin{array}{l}\text { New advanced/industrialized } \\
\text { countries }\end{array}$} \\
\hline Exporters & Emerging & $\begin{array}{l}\text { Advanced } \\
\text { (extended } \\
\text { definition) }\end{array}$ & $\begin{array}{l}\text { DCs and } \\
\text { LDCs }\end{array}$ & Emerging & $\begin{array}{l}\text { Advanced } \\
\text { (extended } \\
\text { definition) }\end{array}$ & $\begin{array}{l}\text { DCs and } \\
\text { LDCs }\end{array}$ \\
\hline$\Delta$ In tariffs & $\begin{array}{c}0.13 \\
(0.14)\end{array}$ & $\begin{array}{l}-0.17^{\mathrm{C}} \\
(0.09)\end{array}$ & $\begin{array}{l}-0.03^{\mathrm{c}} \\
(0.02)\end{array}$ & $\begin{array}{c}0.02 \\
(0.07)\end{array}$ & $\begin{array}{l}-0.01 \\
(0.06)\end{array}$ & $\begin{array}{l}-0.05^{b} \\
(0.02)\end{array}$ \\
\hline $\begin{array}{l}\text { HS6 product } X \\
\text { importer fixed effects }\end{array}$ & Yes & Yes & Yes & Yes & Yes & Yes \\
\hline $\begin{array}{l}\text { Country-pair fixed } \\
\text { effects }\end{array}$ & Yes & Yes & Yes & Yes & Yes & Yes \\
\hline Observations & 454,486 & 529,419 & $4,502,691$ & $1,311,263$ & $1,940,918$ & $11,870,553$ \\
\hline Adjusted R-squared & 0.254 & 0.237 & 0.148 & 0.254 & 0.228 & 0.121 \\
\hline
\end{tabular}

Note: Robust standard errors clustered by country pair in parentheses. Constant \& fixed effects not reported. ${ }^{a} p<0.01,{ }^{b} p<0.05,{ }^{c} p<0.1$. The extended group of advanced countries includes Czech Republic, Estonia, Hungary, Iceland, Israel, New Zealand, Poland, Slovakia and Slovenia in addition to Australia, Canada, EU15, Japan, Norway, Switzerland and the US.

Lastly, Table 8 refocuses on emerging exporters and investigates the impact of tariff cuts on the extensive margin of trade for different groups of products. We refer to the classification in Rauch (1999) and distinguish between organized exchange, reference priced and differentiated goods. Some products do not appear in Rauch's classification which explains 
the slightly smaller number of observations. Also, Rauch (1999) provides two classifications: a conservative and a liberal one. ${ }^{23}$ Table 8 reports the results using the conservative classification. The results are unchanged if the liberal classification is used. The estimated coefficients are almost not significant. The only significant effect of 1996-2006 tariff cuts is observed for new exports of organized exchange goods by emerging countries to new advanced and new industrialized countries in 2006. The absence of significance is not surprising given the absence of the effect found at the aggregated level (Table 6).

Table 8. Extensive margin - Sector analysis

\begin{tabular}{lcc}
\hline $\begin{array}{l}\text { Dependent variable } \\
\text { Model }\end{array}$ & Probability of switch (new bilateral trade flow in \\
Importers & $(1)$ & $2006)$ \\
Exporters & Advanced countries $\quad$ New advanced/ & industrialized countries \\
\hline
\end{tabular}

\begin{tabular}{lcc}
$\Delta$ In tariffs $x$ organized exchange goods & -0.08 & $0.30^{\mathrm{b}}$ \\
& $(0.08)$ & $(0.13)$ \\
$\Delta$ In tariffs $x$ reference priced goods & 0.04 & 0.13 \\
& $(0.11)$ & $(0.08)$ \\
$\Delta$ In tariffs $x$ differentiated goods & 0.32 & -0.01 \\
& $(0.24)$ & $(0.08)$ \\
\hline HS6 product X importer fixed effects & Yes & Yes \\
Country-pair fixed effects & Yes & Yes \\
Observations & 434,273 & $1,251,054$ \\
Adjusted R-squared & 0.254 & 0.254 \\
\hline
\end{tabular}

Note: Robust standard errors clustered by country pair in parentheses. Constant \& fixed effects not reported. ${ }^{a} p<0.01,{ }^{b} p<0.05,{ }^{c} p<0.1$

\subsection{Intensive margin of trade}

We next discuss the results for the intensive margin of trade focusing on strictly positive trade flows in 1996 and 2006. Our dependent variable is variation in the logarithm of the value of bilateral imports between 1996 and 2006, estimated using OLS. The results are reported in Tables 9-11, and are presented similar to the results for the extensive margin of trade.

Table 9 reports the basic regressions. The following main outcomes are observed: ${ }^{24}$

\footnotetext{
${ }^{23}$ The conservative classification minimizes the number of products classified as organized exchange or reference priced; the liberal classification maximizes those numbers (Rauch, 1999).

24

Note that the estimated coefficient on distance is difficult to interpret since our dependent variable is the variation in bilateral exports between 1996 and 2006, and distance is time-invariant.
} 
- If the specification includes HS6 product fixed effects interacted with importer and country-pair fixed effects, tariff cuts have a positive and significant impact on changes to the values exported from emerging countries to advanced $(p<0.01)$ and to new advanced and new industrialized countries $(p<0.05)$ between 1996 and 2006, suggesting that tariff reductions favoring emerging countries tend to promote bilateral trade. The effect is largest for exports to advanced countries.

- The effect of changes in exporter's GDP per capita (current and PPP terms) on the intensive margin of trade is similar to the effect on the extensive margin; there is a positive and significant effect if the importer is a new advanced or a new industrialized country.

- Importer's Herfindahl index has no impact on the exports of emerging countries to advanced countries, but a positive and significant effect is observed for exports to new advanced and new industrialized partners, suggesting that concentration on new advanced and new industrialized destinations mainly benefits to emerging exporters that were already active in these markets in 1996.

So, in the context of our hypothesis linking per capita income and productivity, what is the reason for the increased exports from emerging countries at the intensive margin? It can be explained less by comparative advantage than by firm heterogeneity. As emerging countries become more productive, there are more firms able to export a given product, which affects the intensive margin of exports measured at product level (our data do not account for firm level). Similarly, as the overall productivity of incumbent firms increases, their sales also increase.

Table 10 compares emerging and other groups of exporters. Compared with the results for the extensive margin of trade, we see that emerging countries benefited from the tariff reductions granted by advanced, new advanced and new industrialized importers - and more than the other groups of exporters. Advanced exporters (extended group) received no benefit from the tariff cuts offered by advanced, new advanced/industrialized countries; the estimated coefficients are not significant. DC and LDC exporters benefited from the tariff cuts offered by advanced countries $(p<0.01)$, while the effect is not significant for their exports to new advanced and new industrialized countries.

Finally, Table 11 studies the effects of tariff cuts on the intensive margin of trade for different types of products classified according to Rauch (1999). We observe a significant effect of these cuts between 1996 and 2006 on changes to export values during the same period for differentiated goods (and to a lesser extent reference priced goods). In addition, the magnitude and level of significance of the estimated coefficients are much larger than for the extensive margin of trade. These estimations are based on the conservative classification developed by Rauch (1999); our conclusions do not change if the liberal classification is used. 
Table 9. Intensive margin - Basic regressions

\begin{tabular}{|c|c|c|c|c|c|c|c|c|}
\hline \multirow{4}{*}{$\begin{array}{l}\text { Dependent variable } \\
\text { Model } \\
\text { Importers } \\
\text { Exporters }\end{array}$} & \multicolumn{8}{|c|}{$\Delta \ln ($ imports $)=\ln \left(\right.$ imports $\left._{06}\right)-\ln \left(\right.$ imports $\left._{96}\right)$} \\
\hline & $(1)$ & (2) & (3) & (4) & (5) & (6) & (7) & (8) \\
\hline & \multicolumn{4}{|c|}{ Advanced countries } & \multicolumn{4}{|c|}{ New advanced/industrialized countries } \\
\hline & & & & Emergi & countries & & & \\
\hline \multirow[t]{2}{*}{$\Delta$ In tariffs } & $-2.13^{\mathrm{a}}$ & -0.78 & $-0.91^{c}$ & $-2.24^{a}$ & -0.13 & -0.27 & -0.52 & $-1.43^{b}$ \\
\hline & $(0.81)$ & $(0.60)$ & $(0.49)$ & $(0.85)$ & $(0.65)$ & $(0.43)$ & $(0.42)$ & $(0.59)$ \\
\hline \multirow{2}{*}{$\Delta \ln \left(\right.$ Population $\left._{\text {exporter }}\right)$} & & -0.21 & $2.29^{c}$ & & & -0.96 & 1.32 & \\
\hline & & $(1.24)$ & $(1.17)$ & & & $(0.92)$ & $(1.00)$ & \\
\hline \multirow[t]{2}{*}{$\Delta \ln ($ GDP per capita exporter $)$ (current $\$$ ) } & & $1.05^{\mathrm{a}}$ & & & & $1.06^{a}$ & & \\
\hline & & $(0.19)$ & & & & $(0.16)$ & & \\
\hline \multirow{2}{*}{$\Delta \ln ($ GDP per capita exporter $)($ PPP) } & & & $2.12^{\mathrm{a}}$ & & & & $2.09^{\mathrm{a}}$ & \\
\hline & & & $(0.26)$ & & & & $(0.25)$ & \\
\hline \multirow[t]{2}{*}{$\Delta \ln \left(\right.$ Population $\left._{\text {importer }}\right)$} & & -0.81 & 0.81 & & & 0.97 & 1.55 & \\
\hline & & (2.34) & (1.35) & & & $(1.11)$ & $(1.12)$ & \\
\hline \multirow[t]{2}{*}{$\Delta \ln ($ GDP per capita importer $)$ (current $\$$ ) } & & 0.42 & & & & $0.97^{\mathrm{a}}$ & & \\
\hline & & $(0.33)$ & & & & $(0.16)$ & & \\
\hline \multirow[t]{2}{*}{$\Delta \ln ($ GDP per capita importer $)(P P P)$} & & & 0.50 & & & & $1.23^{\mathrm{a}}$ & \\
\hline & & & $(0.36)$ & & & & $(0.25)$ & \\
\hline \multirow[t]{2}{*}{ Ln distance } & & $0.21^{c}$ & $0.20^{a}$ & & & -0.06 & -0.01 & \\
\hline & & $(0.11)$ & $(0.08)$ & & & $(0.05)$ & $(0.06)$ & \\
\hline \multirow[t]{2}{*}{ Herfindahl Index importer $_{\text {(in 1996) }}$} & & 0.23 & 0.21 & & & $0.46^{\mathrm{a}}$ & $0.75^{a}$ & \\
\hline & & $(0.24)$ & $(0.19)$ & & & $(0.16)$ & $(0.17)$ & \\
\hline HS6 product fixed effects & Yes & Yes & Yes & No & Yes & Yes & Yes & No \\
\hline HS6 product X importer fixed effects & No & No & No & Yes & No & No & No & Yes \\
\hline Country-pair fixed effects & No & No & No & Yes & No & No & No & Yes \\
\hline Observations & 127,886 & 127,886 & 127,886 & 127,886 & 153,223 & 153,223 & 153,223 & 153,223 \\
\hline Adjusted R-squared & 0.097 & 0.130 & 0.142 & 0.194 & 0.056 & 0.112 & 0.115 & 0.229 \\
\hline
\end{tabular}

Note: Robust standard errors clustered by country pair in parentheses. Constant \& fixed effects not reported. ${ }^{a} p<0.01,{ }^{b} p<0.05,{ }^{c} p<0.1$. 
Table 10. Intensive margin - Comparison across groups of exporters

\begin{tabular}{|c|c|c|c|c|c|c|}
\hline \multirow{2}{*}{$\begin{array}{l}\text { Dependent variable } \\
\text { Model }\end{array}$} & \multicolumn{6}{|c|}{$\Delta \ln$ (imports) $=\ln$ (imports if $\left._{06}\right)-\ln$ (imports (if $\left._{6}\right)$} \\
\hline & (1) & (2) & $(3)$ & (4) & & (6) \\
\hline Importers & \multicolumn{3}{|c|}{ Advanced countries } & \multicolumn{3}{|c|}{$\begin{array}{c}\text { New advanced/ } \\
\text { industrialized countries }\end{array}$} \\
\hline Exporters & Emerging & $\begin{array}{l}\text { Advanced } \\
\text { (extended } \\
\text { definition) }\end{array}$ & $\begin{array}{l}\text { DCs \& } \\
\text { LDCs }\end{array}$ & Emerging & $\begin{array}{l}\text { Advanced } \\
\text { (extended } \\
\text { definition) }\end{array}$ & $\begin{array}{c}\text { DCs and } \\
\text { LDCs }\end{array}$ \\
\hline$\Delta \ln t$ & $\begin{array}{l}-2.24^{\mathrm{a}} \\
(0.85)\end{array}$ & $\begin{array}{l}-0.80 \\
(0.49)\end{array}$ & $\begin{array}{l}-1.30^{\mathrm{a}} \\
(0.27)\end{array}$ & $\begin{array}{l}-1.43^{b} \\
(0.59)\end{array}$ & $\begin{array}{l}-0.74 \\
(0.46)\end{array}$ & $\begin{array}{l}-0.38 \\
(0.35)\end{array}$ \\
\hline $\begin{array}{l}\text { HS6 product X } \\
\text { importer fixed effects }\end{array}$ & Yes & Yes & Yes & Yes & Yes & Yes \\
\hline $\begin{array}{l}\text { Country-pair fixed } \\
\text { effects }\end{array}$ & Yes & Yes & Yes & Yes & Yes & Yes \\
\hline Observations & 127,886 & 274 & 82,666 & 153,223 & 379,005 & 63 \\
\hline Adjusted R-squared & 0.194 & 0.135 & 0.137 & 0.229 & 0.190 & 0.182 \\
\hline
\end{tabular}

Note: Robust standard errors clustered by country pair in parentheses. Constant \& fixed effects not reported. ${ }^{a} p<0.01,{ }^{b} p<0.05,{ }^{c} p<0.1$. The extended group of advanced countries includes Czech Republic, Estonia, Hungary, Iceland, Israel, New Zealand, Poland, Slovakia and Slovenia in addition to Australia, Canada, EU15, Japan, Norway, Switzerland and the US.

Table 11. Intensive margin - Sector analysis

\begin{tabular}{|c|c|}
\hline $\begin{array}{l}\text { Dependent variable } \\
\text { Model }\end{array}$ & $\Delta \ln ($ imports $)=\ln \left(\right.$ imports $\left._{06}\right)-\ln ($ imports 96$)$ \\
\hline Importers & Advanced countries $\begin{array}{c}\text { New advanced/ } \\
\text { industrial. countries }\end{array}$ \\
\hline Exporters & Emerging countries \\
\hline
\end{tabular}

\begin{tabular}{lcc}
$\Delta$ In tariffs $\times$ organized exchange goods & 0.18 & 1.22 \\
& $(1.93)$ & $(1.43)$ \\
$\Delta$ In tariffs $\times$ reference priced goods & -0.93 & $-1.40^{\mathrm{c}}$ \\
& $(1.07)$ & $(0.78)$ \\
$\Delta$ In tariffs $\times$ differentiated goods & $-2.61^{\mathrm{a}}$ & $-1.52^{\mathrm{b}}$ \\
& $(0.95)$ & $(0.61)$ \\
\hline HS6 product X importer fixed effects & Yes & Yes \\
Country-pair fixed effects & Yes & Yes \\
Observations & 120,938 & 145,385 \\
Adjusted R-squared & 0.194 & 0.229 \\
\hline
\end{tabular}

Note: Robust standard errors clustered by country pair in parentheses. Constant \& fixed effects not reported.

${ }^{a} p<0.01,{ }^{b} p<0.05,{ }^{c} p<0.1$ 


\subsection{Robustness checks}

This section provides some robustness checks for the results at both the extensive and intensive margins, reported in reported in Tables 12 (extensive margin) and 13 (intensive margin). The baseline results are reported in the first rows of Tables 12 and 13.

We investigate first whether our results are robust to the use of an alternative definition of tariffs. In relation to market access, what is important is not the separate changes in the market access of individual exporters, but the combined outcome of changes in the market access of all competing actors. Thus, instead of accounting only for absolute variations in bilateral tariffs, we take account also of the variations in the tariffs faced by all competitors in the same importing market for a given product in order to explain changes in preference margins, if any. We define a new explanatory variable which captures the relative variation in tariffs faced by each exporter $i$ for a product $k$ on market $j$. This definition follows Fugazza and Nicita (2013) and is calculated as the difference in the variations in tariffs between 1996 and 2006 faced by exporter $i$ for product $k$ on market $j$, and the variations in tariffs over 19962006 faced by all other foreign competitors in the same import market and for the same good $\left(\Delta_{r e l} \ln \tau_{i j k}=\Delta \ln \tau_{i j k}-\sum_{w \neq i} \Delta \ln \tau_{w j k}\right.$ ). The tariff faced by other foreign competitors is computed as the trade weighted average of the tariffs imposed by country $i$ on all exporters of product $k$. The estimations validate our baseline results: the estimated coefficients at the extensive margin are not significant for exports to advanced markets and to new advanced/new industrialized markets, while the estimated coefficients at the intensive margin are negative and significant.

The second robustness check consists of controlling for the initial level of tariffs faced by emerging exporters in 1996. Again, the baseline results are robust. Interestingly, the estimated coefficients of the variable for 1996 tariffs are not significant at the extensive margin for exports to advanced markets and at the intensive margin for exports to new advanced/new industrialized markets but are negative and significant at the extensive margin for exports to new advanced/new industrialized markets and at the intensive margin for exports to advanced countries. This suggests that the low tariffs granted by advanced countries to emerging exporters in 1996 did not facilitate the emergence of new export flows in 2006 but rather deepened and reinforced existing ones. The opposite is true for emerging countries exporting to new advanced and new industrialized countries.

Among missing bilateral trade flows (i.e. zero trade flows), we can distinguish between "true" zeros (i.e. products that are never exported by a country, e.g., because of lack of endowments to produce such goods) and "non-true" zeros (i.e. products that are not traded with some but not all partners). Including all zeros could affect our estimates at the extensive margin; ${ }^{25}$ therefore, for 1996 we identify those products that are never exported by a given emerging country and exclude them from the sample. The results are unaffected by this reduced sample: the estimated coefficients are still not significant.

25

The intensive margin, which focuses only on strictly positive flows, is not affected. 
The fourth robustness check follows Besedeš and Prusa (2011) and refers only to continuous export flows. As Besedeš and Prusa indicate, point-to-point comparisons (1996 vs. 2006 in our case) could be biased if relationships are short-lived. The bias may specifically affect the extensive margin. We reran the estimations dropping all noncontinuous export flows, i.e. flows that appear, disappear and then reappear continuously over the 1996-2006 period. The estimated coefficients remain not significant at the extensive margin and their level of significance at the intensive margin is slightly reduced $(p<0.05$ instead of $p<0.01$ ) although their magnitude is stable.

Our results for both the extensive and intensive margins may be driven by the limited number of products. As additional robustness checks, we repeated the estimations dropping i) agricultural products (HS01-24), ii) mineral products (HS25-27), and iii) the specific sector of arms (HS93). The baseline results remain valid for both margins of trade.

Rather than being driven by particular products, our results may be driven by some specific countries. Our two final robustness checks deal with this potential issue by dropping i) China from our sample of exporters, and ii) all importing and exporting countries not members of the WTO in 1996 and/or 2006 (i.e. China, Russia, and Vietnam). Again, our results are not affected by these exclusions.

\section{Conclusion}

This article analyzed the impact of tariff reductions granted to emerging countries by their main trading partners between 1996 and 2006, on bilateral trade flows in 2006. We investigated the effects on both trade margins.

Our results suggest first that these tariff cuts had very limited impacts on the extensive margin of trade but that some effect is observed at the intensive margin. Sector level analysis based on Rauch's (1999) classification, highlights a positive impact of tariff cuts but only at the intensive margin of trade and for differentiated goods. Our results show also that changes in emerging countries' current per capita GDP and per capita PPP GDP have a significant influence on their integration in the world economy with the effect of variations in per capita PPP GDP being slightly more important.

The small impact of tariff cuts on emerging countries' exports may be explained (among other things) by limited tariff cuts related to those products where emerging countries are competitive or the upholding of tariff peaks in labor intensive products. Another potential explanation could be related to the substitution of tariffs by non-tariff measures. Recurrent tariff cuts and generalized binding would mean that the positive extensive margin of trade associated with trade liberalization would depend increasingly on agreements related to nontariff measures. The study by Shepherd (2007) provides partial evidence of this by relying on harmonization of standards, and using a database of EU product standards in the textiles, garments, and footwear industries. However, this line of investigation is beyond the scope of 
the present paper and would require reliable and exhaustive databases on non-tariff measures.

Table 12. Extensive margin - Robustness checks

\begin{tabular}{|c|c|c|c|}
\hline \multirow{2}{*}{$\begin{array}{l}\text { Dependent variable } \\
\text { Model }\end{array}$} & & \multicolumn{2}{|c|}{$\begin{array}{c}\text { Probability of switch } \\
\text { (new bilateral trade flow in 2006) }\end{array}$} \\
\hline & & $\begin{array}{l}\text { (new bllater' } \\
\text { (1) }\end{array}$ & (2) \\
\hline \multicolumn{2}{|l|}{ Importers } & Advanced countries & New advanced/ \\
\hline \multicolumn{2}{|l|}{ Exporters } & \multicolumn{2}{|c|}{ Emerging countries } \\
\hline \multirow[t]{3}{*}{ Baseline } & $\Delta \ln$ tariffs & $0.13(0.14)$ & $0.02(0.07)$ \\
\hline & Observations & 454,486 & $1,311,263$ \\
\hline & Adj. R-squared & 0.254 & 0.254 \\
\hline \multirow[t]{3}{*}{ With relative variation in tariffs } & $\Delta_{\text {rel }} \ln$ tariffs & $0.15(0.14)$ & $0.10(0.08)$ \\
\hline & Observations & 454,486 & $1,311,263$ \\
\hline & Adj. R-squared & 0.254 & 0.254 \\
\hline \multirow[t]{4}{*}{ With initial tariffs } & $\Delta$ In tariffs & $0.19(0.16)$ & $-0.05(0.06)$ \\
\hline & In tariffs 96 & $0.16(0.14)$ & $-0.66^{\mathrm{a}}(0.14)$ \\
\hline & Observations & 454,486 & $1,311,263$ \\
\hline & Adj. R-squared & 0.254 & 0.254 \\
\hline \multirow[t]{3}{*}{ Without "true" zero flows } & $\Delta$ In tariffs & $0.19(0.15)$ & $0.07(0.08)$ \\
\hline & Observations & 338,786 & 969,463 \\
\hline & Adj. R-squared & 0.252 & 0.261 \\
\hline \multirow{3}{*}{ Without non-continuous flows } & $\Delta \ln$ tariffs & $0.09(0.06)$ & $0.01(0.05)$ \\
\hline & Observations & 415,719 & $1,230,357$ \\
\hline & Adj. R-squared & 0.163 & 0.166 \\
\hline \multirow[t]{3}{*}{ Without agricultural products } & $\Delta$ In tariffs & $0.25(0.20)$ & $-0.01(0.08)$ \\
\hline & Observations & 388,453 & $1,118,531$ \\
\hline & Adj. R-squared & 0.269 & 0.274 \\
\hline \multirow[t]{3}{*}{ Without mineral products } & $\Delta \ln$ tariffs & $0.13(0.14)$ & $0.03(0.07)$ \\
\hline & Observations & 438,759 & $1,269,657$ \\
\hline & Adj. R-squared & 0.255 & 0.256 \\
\hline \multirow[t]{3}{*}{ Without arms } & $\Delta \ln$ tariffs & $0.13(0.14)$ & $0.02(0.07)$ \\
\hline & Observations & 452,746 & $1,306,204$ \\
\hline & Adj. R-squared & 0.254 & 0.255 \\
\hline \multirow[t]{3}{*}{ Without China as exporter } & $\Delta$ In tariffs & $0.13(0.14)$ & $-0.03(0.07)$ \\
\hline & Observations & 441,121 & $1,263,222$ \\
\hline & Adj. R-squared & 0.235 & 0.214 \\
\hline \multirow[t]{2}{*}{ Without non-WTO members } & $\Delta$ In tariffs & $0.17(0.16)$ & $-0.03(0.11)$ \\
\hline & $\begin{array}{l}\text { Observations } \\
\text { Adj. R-squared }\end{array}$ & $\begin{array}{c}413,794 \\
0.240\end{array}$ & $\begin{array}{l}1,045,109 \\
0.207\end{array}$ \\
\hline
\end{tabular}

Note: Robust standard errors clustered by country pair in parentheses. All estimations include HS6 product $X$ importer and country-pair fixed effects. Constant \& fixed effects not reported. ${ }^{a} p<0.01,{ }^{b}$ $p<0.05,{ }^{c} p<0.1$ 
Table 13. Intensive margin - Robustness checks

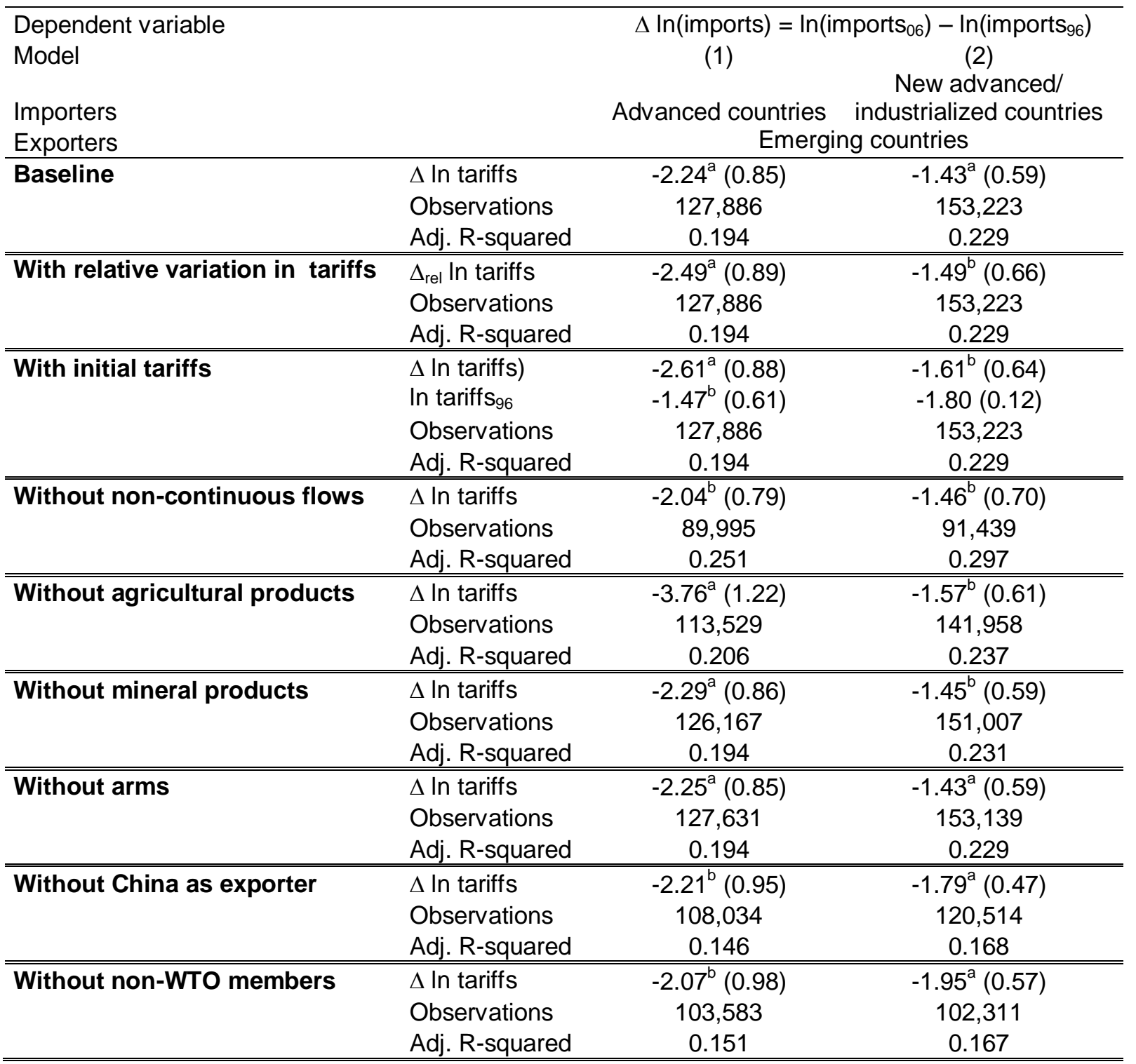

Note: Robust standard errors clustered by country pair in parentheses. All estimations include HS6 product $X$ importer and country-pair fixed effects. Constant \& fixed effects not reported. ${ }^{a} p<0.01,{ }^{b}$ $p<0.05,{ }^{c} p<0.1$ 


\section{References}

AMITI M., FREUND C. (2010), "The Anatomy of China's Export Growth," in Robert C. Feenstra and Shang-Jin Wei (Eds), China's Growing Role in World Trade, NBER: University of Chicago Press, pp.35-56.

Baier S., BergstRand J. (2001), "The Growth of World Trade: Tariffs, Transport Costs, and Income Similarity," Journal of International Economics 53(1): 1-28.

BAYOUMI T., EICHENGREEN B. (1997), "Is Regionalism Simply a Diversion? Evidence from the Evolution of the EC and EFTA," in Takatoshi Ito and Anne O. Krueger (Eds), Regionalism versus Multilateral Trade Arrangements, NBER: University of Chicago Press, pp.141-168.

Besedeš T., Prusa T. J. (2011), "The Role of Extensive and Intensive Margins and Export Growth," Journal of Development Economics 96(2): 371-379.

BOAO FORUM FOR ASIA (2010), "The Development of Emerging Economies - Annual Report 2009," University of International Business and Economics Press, Beijing, China.

BouËt A., Decreux Y., Fontagné L., Jean S., Laborde D. (2008), "Assessing Applied Protection Across the World," Review of International Economics 16(5): 850-863.

BouËt A., Fontagné L., Mimouni M., Pichot X. (2001), "Market Access Maps: A Bilateral and Disaggregated Measure of Market Access," CEPII Working Paper 2001-18.

BUONO I., LALANNE G. (2012), "The effect of the Uruguay round on the intensive and extensive margins of trade," Journal of International Economics 86(2): 269-283.

ChePtea A., FonTAgnÉ L., Zignago S. (2010), "European Export Performance," CEPII Working Paper 2010-12.

DebaeRE P., MOSTASHARI S. (2010), "Do tariffs matter for the extensive margin of international trade? An empirical analysis," Journal of International Economics 81(2): 163169.

FeEnStRA R.C., KeE H.L. (2007), "Trade Liberalisation and Export Variety: A Comparison of Mexico and China," World Economy 30(1): 1-21.

FELBERMAYR G., KOHLER W. (2010), "Does WTO Membership Make a Difference at the Extensive Margin of World Trade?," in Zdenek Drabek (Ed.), Is the World Trade Organization Attractive Enough for Emerging Economies?, New York: Palgrave MacMillan, pp.217-246.

Flam, H., NoRdStRÖM, H. (2007). Explaining large euro effects on trade: the extensive margin and vertical specialization. Stockholm University, Manuscript. 
FRANCOIS J.F., MARTIN W. (2004), "Commercial Policy Variability, Bindings, and Market Access," European Economic Review 48(3): 665-679.

FugAZZA M., Nicita A. (2013), "The direct and relative effects of preferential market access," Journal of International Economics 89: 357-368.

GAULIER G., ZIGNAGO S. (2010), "BACl: International trade Database at the Product-level. The 1994-2007 Version," CEPII Working Paper 2010-23.

HarRison G.W., Rutherford T.F., TARR D.G. (1997), "Quantifying the Uruguay Round," The Economic Journal 107(444): 1405-1430.

HANSON G.H. (2012), "The Rise of Middle Kingdoms: Emerging Economies in Global Trade," Journal of Economic Perspectives 26(2): 41-64.

Hummels D., KLENOW P.J. (2005), “The Variety and Quality of a Nation's Exports," American Economic Review 95(3): 704-723.

KEHOE T.J., RUHL K.J. (2013), "How Important Is the New Goods Margin in International Trade?," Journal of Political Economy 121(2): 358-392.

RAUCH, J.E. (1999), "Networks versus markets in international trade," Journal of International Economics 48:7-35.

Rose, A.K. (2004), "Do We Really Know that the WTO Increases Trade?," American Economic review 94(1): 98-114.

SALA D., SchröDER P.J.H, YALCIN E. (2010), "Market Access through Bound Tariffs," Scottish Journal of Political Economy 57(3): 272-289.

ScHOTT P.K. (2004), "Across-Product versus Within-Product Specialization in International Trade," Quarterly Journal of Economics 119(2): 647-678.

SHEPHERD B. (2007), "Product Standards, Harmonization, and Trade: Evidence from the Extensive Margin,” World Bank Policy Research Working Paper Series 4390.

WoOldRIDGE J.M. (2002). Econometric Analysis of Cross Section and Panel Data. Cambridge, MA: MIT Press.

YI K.M. (2003), "Can Vertical Specialization Explain the Growth of World Trade," Journal of Political Economy 111(1): 52-102. 
Appendix: Countries included in the sample

Exporting emerging countries

Argentina
Brazil
Chile
China
Colombia
Egypt
India
Indonesia
Malaysia
Mexico
Pakistan
Peru
Philippines
Russia
South Africa
South Korea
Thailand
Turkey

Importing countries

Advanced:

$$
\begin{gathered}
\text { Australia } \\
\text { Canada } \\
\text { EU15 } \\
\text { Japan } \\
\text { Norway } \\
\text { Switzerland } \\
\text { United States }
\end{gathered}
$$

New advanced and new

industrialized countries:

Argentina
Brazil
Chile
China
India
Indonesia
Israel
Malaysia
Mauritius
Mexico
Philippines
Singapore
South Africa
South Korea
Sri Lanka
Turkey
Venezuela
Vietnam

